\section{ON THAI TRANSNATIONAL SUBJECTIVITY}

\author{
Sudarat Musikawong ${ }^{1}$
}

\begin{abstract}
This paper examines the formation of transnational subjectivity through Thai political engagements in the United States (US). Thai people in the US participate in Thai homeland politics, while negotiating for a Thai immigrant identity in the US. Thai diasporas exist through political and social experiences, in which Thai communities and persons engage in homeland politics. Political acts and protests by Thais in the United States are not new, but emerged in the aftermath of the Cold War. This paper asks how political exiles, popular protests, film festivals, and satellite television challenge what Benedict Anderson has termed "long-distance" nationalism and Arjun Appadurai's mediascapes.
\end{abstract}

\section{Introduction}

Thais in the United States (US) have been integral participants in the issues of democracy, human rights, migration and immigration through their transnational political ties between Thailand and the US. The United States has long been a 'home' away from home in which Thai politics are negotiated, especially in light of the history of US counterinsurgency in Southeast Asia. In the aftermath of the October 14, 1973 uprising that led to the demise of the Thanom Kittikajorn military government, US political analysts

${ }^{1}$ Assistant Professor, Department of Sociology, Siena College, New York. misleadingly considered Thailand to be the "next domino" to fall to communism. The US was actively contributing to military authoritarianism abroad to fight socialist communism (Bradley 1978). The US Congressional Hearings on Human Rights in Thailand marked an end to US military aid sent to Thailand after the October 6, 1976 massacre. The testimonies by Thai nationals examined in this paper were transnational political acts.

The scope and scale of Thai political homeland transnationalisms in the United States is a subject greatly understudied. Several contemporary events point to the formation of Thai political experiences that occur through travel between Thailand and the United States, involving Thai transnational political engagements in the United States. Such events include the public participation of political exiles from the 1970s, the May 1992 demonstrations among Thai diasporas in Los Angeles against the Thai state's crackdown on democracy demonstrators in Bangkok, and the 2004 film festivals in Los Angeles and New York City. Much of the literature about memories of 1970 s Thai state violence has remained primarily focused on the contest over Thai historiography contained within the borders of Thailand (Somkiat 1978, Nidhi 2002, Charnvit 2001). Yet, memories about 1970s state violence have traveled between Bangkok and US cities, through the 1977 travels of political exiles to testify at the US Congressional Hearings, and the 2000s resurgence of interest in the October 14, 1973 uprising against the military dictatorship and the October 6, 1976 massacre of the student movement among diasporic Thai communities in the United States. Beside cultural activities involving memories of both of these October events, political activities in New York City 
included demonstrations against former Prime Minister Thaksin Shinawatra during the United Nations 2006 meeting. Activist organizing against the Thai government and 2006-2007 military junta in major US cities was a key highlight of transnational Thai homeland politics. These transnational activities form a range of direct political/cultural engagements that reveal the contextual and fragmented nature of the "Thai transnational" subject. The formation of Thai transnationals in places such as Washington DC, Los Angeles, and New York reveals multiple political subjectivities in conflict over what constitutes democracy and belonging, and that are ultimately dangerously bound to nationalism.

\section{Making the Thai political subject transnational}

The research on Thais in the United States in general is limited. I suggest it can be rooted in two diverging premises. One is based on the study of Thai economic immigration to the United States. The other focuses on transnational Thai homeland political engagement as a vibrant from of social and cultural practice. As part of the historical migration of mainland Southeast Asians to the United States, most Thai immigrants are distinct from their regional counterparts, who are mostly displaced refugees from the US wars and their aftermath in Vietnam, Laos, and Cambodia. Initial Thai migration in the 1970s-1980s stemmed primarily from the middle and elite classes who attended university in the US and applied for residency, or who migrated via their professional status in fields such as medicine and engineering. Many of this first wave of Thai immigrants were able to sponsor immediate family members for reunification under the United States 1965 Immigration Act. By 1975, while over 30,000 Thais resided in the United States, more accurate estimates were as high as 200,000 , with most being women and children. In the mid 1970 s, $42 \%$ of all Thais admitted were wives of American citizens. While some university students returned to Thailand, some did stay, but not in significant numbers to constitute a "brain drain" (Desbarats 1979: 304-306). Family reunification immigration was at its height in the 1980s and constitutes the second wave of Thai migration. Some thirty years later, in the wake of the 1997 Asian economic crash, many workingpoor Thais migrated to the United States, overstayed their visas, and found work. This is the third wave of migration. In 2000, demographically Thais increased in their relatively small numbers in official numbers in the United States to over 150,000 as documented by the U.S. Census. However with Desbarats' estimation of 200,000 Thais in 1975, it would suggest that there are at least four times more Thais in the US.

There are essentially, two Thai diasporic communities: 1) earlier immigrants with Green Card/ US citizen status tied to Thai middle class politics in Thailand since the 1970s and 2) an emerging working class of poor economic migrants who have both documented and undocumented status. ${ }^{2}$

\footnotetext{
${ }^{2}$ Within the context of US debates on "illegal immigration" there has been an effort by hyper-nationalist nativists to name racially non-white immigrant persons as "illegals." In a counter-discursive move, immigrant rights advocates have sought to use the term documented and undocumented immigrants to decriminalize immigrants who have not received government documentation for their presence in the US. The 2000 US Census does
} 
Within migration from Asia to the United States, there is an observable pattern of bifurcation or bipolarization between affluent middle class Asians and more recent economic migrants (Takaki 1998). This may be also true for Thais in the US. Evelyn Hu-DeHart (1999: 16-17) suggests that this bifurcation is symptomatic of the ways global capitalism has uneven effects upon different economic class communities within one ethnicity. In Los Angeles, New York, and other urban ports of entry, Thai temples, consulates, small markets, and video stores emerged as centers for Thai social life, but incorporating the working poor and middle classes quite differently. In this article, however, I will focus primarily on Thais who have engaged in homeland politics as part of an emerging Thai immigrant middle class in the United States.

The work on transnational and diasporic communities varies across academic disciplines. In media studies, Stuart Hall (1990) argues that conditions of decolonization created influxes of Black Diasporas in Britain. These postcolonial subjects produced cinema and other media that connect displaced peoples with their histories, in a process that served to "enunciate" their identities. This is equally true of Thai diasporas when exhibitions of Thai media and video take place in centers for Thai immigrant social life. However, "Ethnic" enunciation is far from stable or removed from the sometimes violent politics of identity. For Hall, the project of "de-coupling" ethnicity from nationalism reveals the fluid and contextual nature of how ethnic-racial identity as "black" "is essentially a politically and culturally constructed

not accurately represent actual population, especially for the undocumented. category, which cannot be grounded in a set of fixed trans-cultural or transcendental racial categories..." (Hall 1996: 443, 448).

Informed by Hall, James Clifford (1994) posits that diasporas cannot be contained by assimilationist formations of the immigrant. For both Hall and Clifford, diaspora is in tension with nativist identity formations of national hegemonies, invoked increasingly by displaced peoples with a connection to a prior sense of homeland. Displacement of these migrants occurs under the pressure of political violence and transnational capitalism that simultaneously enables relative mobility between homelands and major international cities. In the case of Thai immigrants, in urban centers like Los Angeles and New York, the production of October 1970s memories suggests a transnational Thai subject who travels both physically and ideologically between Thailand and the United States, participating in homeland politics.

In conversation with notions of diaspora, Aihwa Ong (1999, 2006), argues that capitalist neoliberal systems offer state regulated rights that privilege a "flexible citizen." This flexible citizen labors as a subject skilled and predisposed to care of the self for the purpose of maximizing profit. For Arjun Appadurai (1996), the porous boundaries of the nation-state through the traffic of transnational mediascapes creates imaged selves via satellite television, the global commerce of cinema, video, restaurants, sports, and tourism. While Ong maintains a tension with the nation-state and Appadurai notes a need to go "beyond" the nation-state, both problematically presume a political subject premised on social experiences of the cosmopolitan in which the state no longer plays a significant role. These 
conceptualizations of the citizen-subject in studies of transnationalism came in the late 1990s at the height of economic neoliberalism. Conceptualizations of the transnational subject depend on contexts of time and place. Yet, clearly the role of the state in determining belonging to nation has far from vanished. The formation of Thai transnational politics is mediated by long distance nationalism. According to Benedict Anderson, "electronic communications, combined with the huge migrations created by the present world-economic system, are creating a virulent new form of nationalism, which I call long-distance nationalism: a nationalism that no longer depends as it once did on territorial location in a home country" (2001: 42). This paper points to the tensions over defining "Thai-ness" as a viable ethnic, democratic, political, historical transnational subject, as social practices that foreshadow the virulent nationalism of the contemporary era.

Before illustrating these tensions in transnational homeland politics, I want to call attention to the fact that not all Thai immigrants participate in homeland politics in the same way. Saskia Sassen (2003) argues that the less privileged denationalized citizen can demand accountability from global economic and political entities through activist politics located in the global city. Thai communities in the US have struggled with these very issues by engaging in Thai politics at Thai embassies and consular offices, most recently illustrated through the demonstrations in Los Angeles, New York, and Dallas against ousted Prime Minister Thaksin Shinawatra by the transnationally organized People's Alliance for Democracy/ Phanthamit Phuea Prachathippatai [PAD], a strategic alliance between royalists and some progressive activists. Furthermore, other strategic alliances between Thaksin's strains of populist capitalism and competing groups of other progressives have also organized transnationally. While within Thai immigrant communities there is some homeland political participation among the newly arrived working poor, it is predominantly the established Thai immigrants that participate in organizing political and cultural events related to remembering the 1970s.

Many of the more established immigrants constitute an emerging Thai middle class in the US. Jiemen Bao (2005) focuses on middle class' transnational economic ties through the Thai temple as a space in which cultural capital and social status is achieved within Thai diasporic communities. Bao illustrates Ong's idea of flexible citizenship by demonstrating how Thai Buddhist merit making converts economic capital into cultural capital (Bao 2005). Given different notions of Thai identity forged out of displacement (economic and political), I suggest that a focus on Thai transnational identity is better understood not necessarily as Aihwa Ong's privileged flexible citizen (1999), but more broadly as a bifurcated Thai political subject that intervenes in Thai politics by crossing national borders between Thailand and the US. One political subject emerges through the necessity of economic migration and the other seeks fulfillment as a political subject through a tie to homeland histories and politics. I would like now to turn to this second Thai transnational political subject by resituating the cultural memories about the 1970s leftist social movements between Thailand and the US through leftists' and intellectuals' engagement with the US government in 
1977 and through their more recent 2003 engagement with Los Angeles-based Thai temples, and university alumni organizations connected to homeland politics.

\section{October Memories:}

"... it is because you do not have to live in Thailand as a Thai citizen."

- Dr. Puey Ungpakorn, testimony to US Congressional Hearing on Human Rights in Thailand.

October 14, 1973 (a civil uprising in which 500,000 demonstrators in Bangkok helped to oust the military regime) and October 6, 1976 (a massacre of student demonstrators protesting the return of the regime) mark the experiences of a generation of Thais who participated in the social movements of the 1970s. These two events are pivotal to the violence committed by the state during the 1970 s against the leftist and student movements. While the military and institutional powers forced order and obedience to the nation, Buddhism, and the King, leftist student movements were inspired by a combination of reform, royalist democracy, Marxist-Leninist, and Maoist ideals. Although the Bangkok popular uprisings of October 14, 1973 successfully led to the ousting of the Thanom Kittikajorn military regime, the demonstrators suffered great losses with the police and military shooting into the crowds, killing 77 people. October 1973 ushered in the height of student involvement in labor disputes and land reform as well as a counter-wave of rightwing reactionary organizations through vigilante and paramilitary groups. On October 6, 1976, while five thousand college students and supporters were protesting against the return of General
Thanom inside the gates of Thammasat University in central Bangkok, the Thai military, police and right-wing paramilitary groups attacked the demonstrations. The assault escalated into a brutal massacre in which 48 people were brutally killed. The late 1970s marked a mass exodus of students and leftist organizers to join the Communist Party of Thailand (CPT) in the provincial border regions, only to return to major cities in the 1980s defeated and "pardoned" under state amnesty. This amnesty and public silence left both critical events unsettled, and memories of the leftist movements marginalized as a lost cause of the Cold War.

In the 1970s, these traumatic memories were a fresh stain for those who personally experienced them. Many student activists went underground to join the Communist Party of Thailand (CPT) and were instrumental in developing an international network organization against authoritarian rule in Thailand. Fresh memories about Thai state violence traveled to the US, Europe, and Australia with activists organizing talks, publications (Bouehapakdee 1978), and the 1977 US Congressional Hearing testimonies on human rights in Thailand.

The Congressional Hearings were to hear the testimonies on how US military aid to Thailand contributed to the decline of human rights in the country. During this special session of the US Congressional Hearings, public figures like Sulak Sivaraksa and former Thammasat University Rector Puey Ungpakorn as well as an American political scientist W. Scott Thompson were present to testify. ${ }^{3}$ I will

\footnotetext{
${ }^{3}$ Puey Ungpakorn was red-baited and accused of being a communist sympathizer, responsible
} 
focus on the exchanges between Puey and Thompson. Thompson saw insurgency and civil rights as separate issues. $\mathrm{He}$ compared the Thai one percent loss of life due to Cold War conflict against Cambodia's extermination of one-quarter of its population, and suggested that such loss of life was worth the risk of foreclosing the possibility of another Khmer Rouge problem. Furthermore, Thompson considered right-wing violence against leftists under the Thanin Kraivixien government (1976-1977) as a concern of domestic affairs, and not as a violation of human rights. For him, the US objective was clear: US interest in regimes of other countries was to secure US military strategic locations and economic interests. According to Thompson, "letting more countries go communist" would weaken the western international system based on free enterprise that had been in place to US advantage since the end of WW II (United States Congress 1977: 62-63), with the US setting the rules for the World Bank, International Monetary Fund, and the United Nations. While the US was not directly involved in rearticulating the October events into Cold War discourse, US economic and political interests

for supporting the student demonstrations on October 6, 1976. When Thammasat

University Rector Puey Ungpakorn was exiled in England after the October 6 massacre, he traveled to the US to testify in 1977 . W. Scott Thompson is a political scientist. United States. Congress House. Committee on International Relations. Subcommittee on International Organizations., Human Rights in Thailand: Hearings before the Subcommittee on International Organizations of the Committee on International Relations, House of Representatives, Ninety-Fifth Congress, First Session, June 23 and 30, 1977, International Human Rights (Washington: U.S. Govt. Print. Off., 1977). financially fueled the police-military apparatus that ultimately used the October events to justify the need for counterinsurgency funding and a continuation of armed assault against the student movement and the CPT. ${ }^{4}$ When Thompson began speaking in abstract terms, Puey Ungpakorn pointed out how easy it was for Thompson to talk about indifference curves and the ability for the Thai government to withstand an exodus of academics, students, and liberals because Thompson did not have to live in Thailand as a Thai citizen. ${ }^{5}$ For Thompson, even four years after the Congressional Hearings, Thailand and much of Southeast Asia was still in constant threat of communism (Randolph 1981). Contrary to Thompson's claim that Thais publicly spoke of the desire for order, Puey Ungpakorn reminded the US

\footnotetext{
${ }^{4}$ In 1974 , the US spent $\$ 29$ million in military and economic aid to Thailand. David Morell and Susan Morell, "Thailand and the U.S.," New York Times, November 221976. According to Thomas Lobe (1977), the US funded the Joint US Military Advisory Group (JUSMAG) through the CIA to assist Thailand's counterinsurgency efforts. In addition, the US Agency for International Development (USAID), US Operation Mission (USOM), Office of Public Safety, the World Bank's Development Committee (DEVCOM), and US Information Service (USIS) funded the very structures of Thailand's police state. Specifically, US funding was used to fund the Border Patrol Police, Internal Security Operations Command (ISOC), National Security Command, and the Police Aerial reinforcement Unit. Thomas Lobe, United States National Security Police and Aid to the Thailand Police (Colorado: University of Denver Graduate School of International Studies, 1977).

${ }^{5}$ United States. Congress. House. Committee on International Relations. Subcommittee on International Organizations., Human Rights in Thailand, 63.
} 
congress audience that terror and fear of state violence forced Thais to say just that.

The contrast in how memories of the October 6 massacre are differently articulated reveals that for Puey Ungpakorn, the October 6 event was a human rights violation, while for Thompson, it fitted into the narrative of constant encroachment of communism into Southeast Asia. The hearings are not generally mentioned in Thai Studies approaches to understanding the October 14 uprising and the October 6 massacre, but acted as an event contributing to the close of the Cold War in Thailand through transnational political engagements of notable Thai public intellectuals in exile. Ungpakorn lived the rest of his life in Britain.

In contrast to the idea that the October 6, 1976 massacre represents a culmination of tragic massacre, or nostalgic leftist lament, the 1977 US congressional testimonies (as memories produced one year after the massacre) reveal a competing scenario of continuing human rights urgency on the part of victims of the Cold War. I cite this case because it indicates that the notion of a Thai transnational political subject in the US is hardly new. Thai transnational political subjects emerge out of the tensions of US intervention in Southeast Asia. This Thai political subject can be traced to the Cold War period and preceding eras in places figuratively spanned between the massacre site of Thammasat University and Washington D.C.'s Congressional Hearings.

\section{Public remembering, private memories}

Representations of the traumatic episodes from the 1970s Thai Cold War traveled to the US via community organizations and film festivals. In 2001, while Bangkok commemorations of the $25^{\text {th }}$ anniversary of the October 6 massacre and the opening of the October 14 uprising Memorial site were underway, historian Charnvit Kasetsiri, based at Thammasat University, traveled to the Los Angeles Thai temple to screen and discuss his documentary, The October 14 Student Uprising (1998). ${ }^{6}$ While I was attending the October commemorations in Bangkok, my parents were attending the Los Angeles screening of Charnvit's film, along with other members of the Thammasat University Alumni Association (Musikawong 2010). For many of this older generation of Thammasat University graduates who left Thailand before the social movements of the 1970s, watching the film and participating in discussions of Thai politics was a way to connect to their sense of homeland and the generation of student activist university alumni who had immigrated to the US in the 1980s. For many, being an immigrant in the US meant a downward move in terms of social

\footnotetext{
${ }^{6}$ As an established academic and public intellectual, Charnvit Kasetsiri also relied on his connection to universities, arranging screenings at the University of Hawaii and Cornell University. Benedict Anderson worked with Charnvit to provide the subtitling and English text chronicling the events that had led to the uprising in 1973 that accompanied the booklet distributed with the film. Thai communities in the US are connected with Thai intellectuals as well as scholars of Southeast Asian Studies through spaces like the Thai temple, university, and community centers.
} 
economic status, working in manual labor; but being connected to friends through the Alumni Association meant that one had a biography prior to the harder life in the US. For some of this older generation's children in their teens, it was simply about connecting to Thai identity in terms of culture.

That same year in October 2001, Five Star released Moonhunter, directed by Bandit Rittakol and co-written by Seksan Prasertkul. It is a biographical film about former student organizer Seksan Prasertkul, who had become one of the iconic figures of the 1970s student movement. Many of this generation were now academics and had attended graduate school in the US, Australia, and Europe after leaving the Communist Party of Thailand. Moonhunter is titled after a scene in which Seksan shoots at the moon, mistaking it for a Thai military searchlight. In the scene, his hill tribe guides laugh at him because one cannot shoot at the moon, which Seksan believes to be symbolic of his generation's efforts to create revolutionary change. The film juxtaposes scenes of the days during the October 14 uprising, when Seksan and several other student organizers led 500,000 demonstrators in Bangkok against the Thanom Kittikajorn military government, with his days fighting alongside the Communist Party of Thailand [CPT] in the late 1970s. In the final scenes, as Seksan and his wife, Jiranan Pitrpricha, leave the CPT, a voice-over monologue closes with "I am a historical wreck" (Bandit 2001). Both juxtaposed experiences tell of leftist lament, of failed revolution, and social change. While the film played in Thailand's commercial theatres, it soon traveled to the Thai grocery store and video outlets of major US cities in the form of VCD/DVDs and VHS tapes, some pirated, others legitimately produced. In fact, the video store played a pivotal role in providing access to the film for Thais living in Los Angeles.

Four months after its Thai release, Moonhunter had a theatrical premier in the US at the Los Angeles Asian/ Asian American film festival. Visual Communications, a community-based media arts organization that emerged out of the 1970s Asian American movement, organizes this festival every year. One of the most difficult obstacles for festival organizers in reaching out to Thai communities in Los Angeles as potential audiences was the fact that many Thais who might have been interested had already seen the film through video store outlets. Another disconnection between this particular film festival and the Thai communities of southern California was that the organization itself did not involve any Thai organizations in the screening. With a small staff, efforts to contact and work with Thai community members was a difficult task. With the exception of myself and two others, the audience for the film festival premier was primarily twenty or so non-Thais, some Los Angeles progressives, and people who had lived in Thailand during the 1970s. Moonhunter's circuit of distribution for a Thai diaspora was the video store and the circuit of exhibition was the individualized space of the family living room. The consumption of leftist lament by Los Angeles based Thais was thus essentially a private affair.

In contrast, The October 14 Student Uprising's circuit of exhibition was Charnvit's connection to the Thammasat University Alumni Association, which enabled a screening at the space of the Thai temple in Los Angeles. At the level of narrative, The October 14 Uprising is a 
documentary about the 1970s student movement, with the implicit support of the King, earning a victory in ousting the military regime. By contrast, Moonhunter is a narrative feature about the internal conflicts within the student movement and the Communist Party of Thailand from the point of view of a defeated iconic former student activist. The circuits of distribution and exhibition point to the formation of Thai cultural practices that link the Thai immigrant physically situated in Los Angeles to Bangkok media and politics. However, not all cinematic memories about the 1970s student and radical leftist movements circulate under the same terms. When Visual Communication's festival curator, Abraham Ferrer was considering a film from Thailand to represent the alleged emergence of a "renaissance" in Thai cinema, he debated between director Chatri Chalerm Yukol's Suriyothai (2001) and Moonhunter (2001). Suriyothai is a royal nationalist megafeature about a $17^{\text {th }}$ century queen who sacrifices herself to save her King and Siam (pre-nation-state name for the territories) from the invading Burmese forces. Eventually, Suriyothai was remade for a "western" audience through Chatri Chalerm Yukol's transnational collaboration with his former University of California Los Angeles film school classmate, Francis Ford Coppola. Given Visual Communications' sympathies for independent films and leftist politics, the curator ultimately selected Moonhunter for the festival, knowing that there would only be a small audience in attendance. While Thai immigrants celebrated the victory of the October 14 uprising at the temple, the pain of leftist defeat found a Thai audience only in the privacy of one's home.

In 2003, Somchai Thaitan, a businessman importing Thai home décor and media products and an active participant in the Los Angeles Thai community, chaired the organizing committee to commemorate October 14 as a "Day of Democracy" as instituted by Parliament that year. Somchai had been a politically active Ramkamhaeng student in the 1970s, who immigrated to Los Angeles in 1980 to join his family in Southern California. When Somchai first arrived, he worked in a plastics factory and then went back to school to study computer programming, finding employment in that field, and later becoming a well established entrepreneur and Thai socialite (Panu 2003). Personal friends with members of parliament like the Chair of the October 14 Day of Democracy Committee, Somsak Prisananthakul, Somchai and many other Thais in Los Angeles organized commemoration activities at Wat Thai in North Hollywood. While debates about immigrant assimilation/acculturation into host countries often argue that, in order to survive, immigrants sever their ties to their homelands and assimilate, Thais like Somchai are transnational subjects traveling physically and politically between a sense of "homeland" and their place of residence in Los Angeles. Recognizing transnational subjectivity demands attention to the complexity of negotiating being (economically and politically) in between "states" and the notion of "Thainess" that reveal how the latter's sense of national histories are transportable.

The events at Wat Thai in Los Angeles included merit making for those who had died, a concert with Nga Caravan and Ponsit Kampee, and a panel to discuss democracy and history with academics like Charnvit Kasetsiri and Members of Parliament (from Thai Rak Thai, Democrat, and Chart Thai Parties) and 
representatives from the Ministry of Education (Kluykiengchon 2003). The documentary by Charnvit was again featured as a major part of the commemorations but as a mass give-away of 1,000 VCDs to the people who attended the activities. The documentary reveals not only the events leading up to the October 14, 1973 uprising, but also posits the story of Bangkok as central to national democratic social movements. In addition, there was a photo exhibition at the Los Angeles Wat Thai that focused on the events leading up to October 14, 1973 with explanations in Thai and English, a dimension that Somchai explained as designed to reach out to all Thais, suggesting a way to connect younger generations of children who could not read Thai to this aspect of "Thai national history." The dynamism of the visual medium, here both VCD media and photography, is harnessed as a way to transport a sense of Thai national history, connecting Thai diasporas and secondgeneration Thai youth born in the US to Thai identity. Thai transnational history and subjectivity are articulated the space of Bangkok and in the monumental time of the 1970s democratic movement.

In 2003 to cover the expenses of organizing the commemoration, Thais in Los Angeles collected substantial donations, the Thai Parliament budgeted some travel assistance, and members of Parliament's October 14 Day of Democracy organizing committee paid their own travel costs. ${ }^{7}$ It was perhaps the largest commemorative activity for October 14 outside of Thailand, which brought vibrant debates in the newspapers and on internet Blogs for Thais in the US. Jankrapau (pseudonymous columnist for

${ }^{7}$ Panu Neutini, "Somchai Thaitan Interview."
Siam Chronicle USA Newspaper) alleged that Somchai did not understand history and that the over-emphasis on the October 14 uprising displaced the significance of the end of absolute monarchical rule on June 24, 1932, the role of the People's Party, and the October 6, 1976 massacre as part of the nation's democratic history. More interestingly, Jankrapau contended that "Thais in the United States know how to use rights and freedom without relying on commemorating [October] because the way of life of Thais in America is already saturated with freedom in such a way that it is in the blood and bone" (Kluykiengchon 2003). The desire for some Thais in the US from the October generation to connect with homeland politics is tempered by others who do not identify with that group, but who nevertheless lay claim to understanding a more comprehensive notion of national democratic history. There were similar debates about the over-emphasis on October 14 as Day of Democracy in Thailand; however, the major difference was an assumption that living in the US meant that democracy was already fully integrated into one's "blood and bone." A claim that is not necessarily true, but more revealing about the political resentment and fragmentation among the Thai diaspora over what constitutes being connected to Thailand. The tensions and fragmentation intrinsic to these disputes over claims to Thai nationalism solidify the coupling of "Thai ethnicity" with nationalism, in what Stuart Hall terms a practice of epistemic violence from the policing of what is "Thai" from inside the ethnic group (Hall 1996, 445). The deep desire for an identification with democracy and claims to nation is a form of epistemic violence because of its denial of the full range of democracy and belonging without nationalism (in non-monarchical and non- 
Thai ethnic terms). The assumption that modern democracy exists in the blood and bones of those who reside in the United States is a misrecognition that democracy resides in place rather than social practice, and it infantilizes Thai struggles as somehow less democratically mature, less modern.

When the story of the October uprising is told as memories of leftist lament, they are privatized in the space of the home. When the story of the uprising is celebrated as a milestone of Thailand's path to democracy supported by the King, it is publically acknowledged in the communal space of the Thai temple. When the celebration becomes self-congratulatory politicking by Thais in Los Angeles, that history is greeted with resentment. Together these versions of October 14 and October 6 travel from Bangkok to Los Angeles in contrasting senses of a transnational Thai historical subject tied to the Thai nation's ideological conflicts during the Cold War. I want to suggest that when the 1970s student and revolutionary movements are remembered as regrettable, it cannot become a moment in which to bring Thai communities in the US together. For the transnational Thai political subject to lay claim to homeland histories, it is easier when they are celebratory democratic histories. What is it about a transnational sense of public Thai self-imagining that requires seamless historical victories at the abandonment of complex conflicted histories?

\section{Transgenerational forgetting: from Bangkok to New York}

By the late 1990s, politicians incorporated the October 14 uprising into a national discourse about democracy. Conversely, the October 6 massacre became a tragedy that many forgot (Thongchai 2002). In 2003 in Bangkok, the Thai Film Foundation and the October 14 Memorial were interested in exploring how to increase ways that both events were being remembered in opposition to each another. I was fortunate to have collaborated with these two organizations in hosting a video collective workshop for young people under 25 years of age to create short videos about "October," interpreting what the significance of the 1970s social movements were for their generation. For seven weekends, twenty participants watched old found footage of both events, read about and researched the events together. They were visited by former student organizers like Jiranan Pitrpricha and Sinsawat Yaudbangtheuy, and went on a walking tour of both October events' landmark sites in central Bangkok.

The participating youth produced three different films distributed as the October Youth Short Film Project. Full Moon tells the story of a disillusioned 'Art for Life' fan out of touch with contemporary times. The Wall is an experimental documentary with various Thais from all walks of life writing graffiti on a wall, with sound overlaid from an interview with Wat Wunlayangkul, a well known leftist activist from the 1970s. In Night for Freedom, a young man, whose parents died during the 1970s political turmoil, reckons with his gay libido. One workshop participant, Doungta Patummasoot said: "I learned something about political trauma and about forgetting. I don't think violence is the answer to political problems." She coproduced The Wall with three other young people. She continued, "[n]ot only has each of us learned something about teamwork and the film-making process, we each, in our own way, have acquired a 
memory of the October incidents" (Alongkorn 2004). Those memories acquired were in no doubt partial, discontinuous, pro-student movement. While the curriculum of the workshop was predominantly from the perspective of the student movement, we gave the participants free license to interpret the past in terms of any genre, documentary, experimental, narrative, and even satire.

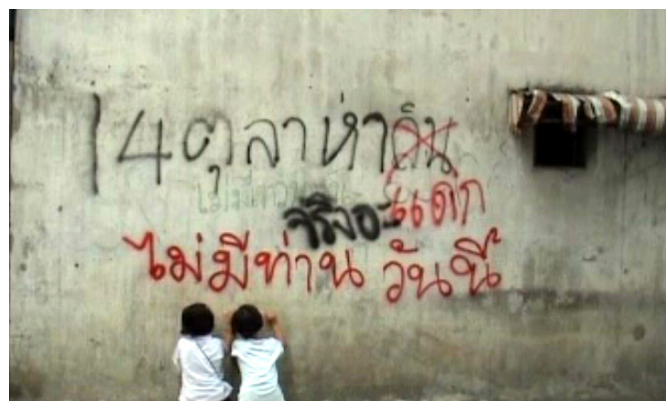

The Wall (2004), translation by author:

"October 14 viciously devours" (top line); "really?" (middle); "there is no you today" (bottom line); Photograph Still CreditThai Film Foundation

While some who experienced the October 6 massacre first-hand were traumatized, having been silenced for so many years, a younger generation does not "acquire a memory of the October incidents," as Doungta asserts, but rather re-scripts those memories in the practice of forgetting. The experimental film The Wall begins with the rude graffiti by one young man, "October 14 hustle/ ha kin;" another young man subsequently crosses out eat/ kin and replaces it with the even more vulgar rendition of kin, "viciously devour/ daek." The people writing the graffiti include an ordained novice monk, a young man in torn up military fatigues, a young woman with a school bag, two young school girls, a homeless man, and others.
Some write "Without them [those involved in October], there would be no you today." Others write, "I don't care, I have no food and I am hungry." The last scene shows the shop owner, to whom the wall belongs, coming out and painting over all the graffiti. The camera zooms in on the painted wall with only "Love the Reader" left in small hand-writing, suggesting that October is left for the audience to read, interpret, and find their own meaning. The visuals are overlaid on the soundtrack with Doungta's interview with famous 1970s activist Wat Wunlayangkul and the British pop song "Sing" by Blur as well. The visual and audio tracks are thus completely disconnected. While the visual is a reckoning with the fact that the 1970s October 14 uprising is disconnected from the experiences of everyday life in present-day Thailand, the audio interview pays tribute to the student movement through a 1970s activist's retelling of the political and economic contexts for the uprising and how Thaksin's politics in 2004 was a military dictatorship under elected means.

The three short films, including The Wall, were screened at several film festivals in Singapore, Bangkok, Los Angeles, and New York. In May 2004, despite advertising in Thai Town, nobody from the Thai communities in Southern California attended the Visual Communications screening in Los Angeles. The curator programmed the three shorts as part of a series on activism and many in the audience were non-Asian city residents, film students, and Asian American students interested in the topic. Without a background in the political events of the 1970s in Thailand, many in the audience remarked that they did not understand the films' historical references. 
In April of 2004 in New York City, Thai Links programmed the October Youth Short Film Projects in their $2^{\text {nd }}$ Thai Takes Film Festival. Thai Links is a ThaiAmerican organization dedicated to "increasing awareness on issues affecting Thai communities at home and abroad through art and activism" (Thai Links 2006). With a small voluntary staff of mostly US-born Thais, Thai Links (20022009) was a creative collective that began to address the need for critical dialogue among a growing population of Thai Americans in the city and an emerging generation of artists and independent filmmakers in Bangkok. With the emerging recognition of independent Thai cinema at international film festivals, Thai Links has been providing a venue for Thai independent films in New York City through festival, panels and other activities.

At the screening, both myself and Thai Film Foundation director Chalida Uabumrungjit were invited as guest speakers for the film. In contrast to the Los Angeles screening of Moonhunter, the audience was a mix of Thai Americans affiliated with Thai Links, Thais who were former student activists and had immigrated to the US in the 1980s, and other New Yorkers. A former student activist who resided in New York where he had been working and struggling as an artist remarked that, for him, having left Thailand so long ago and not having gone back, it was the first time he was able to see and talk about the October 6 massacre. He recounted his own memories about the brutal killings and was visibly shaken. When Chalida and I spoke to him privately, he was glad to see that this moment in the past mattered to a generation of younger Thais but, when asked, he would not give his full name.
His distrust was not unwarranted, given the degree to which those on the left were forced underground. With Thai Links' mission of creating what constitutes a sort of reversal with linkages between Thailand "abroad" and New York "at home" through art and activism, the film festival became a critical site for creating connections for US-born Thai Americans. For many Thai Americans, "abroad" meant outside of the US and "home" was the United States. But for others like the former student-artist activist, even as a US resident, his "abroad" was New York and "home" was Thailand. When Thai Links programmed the October Youth Short Film Project, it also created temporal links between the 1970s and 2004, between an older generation of Thai immigrants who were activist-artists and those who are Thai Americans.

While most of the organizers of Thai Links are Thai Americans in their late 20s30s, when the People's Alliance for Democracy $[\mathrm{PAD}]$ was organizing transnationally against Prime Minister Thaksin, politically active older Thai immigrants worked for the first time with Thai Links. While Thaksin's war on drugs in 2003 killed thousands and the 2004 militarization in the South led to the Takbai massacre of 78 Muslim demonstrators, all of which caught the attention of the United Nations Human Rights Commission, it was in 2006 when Thaksin was accused of being anti-royalist and securing untaxed revenue when he sold his Shin Corp-a Thai media and telecommunications conglomerate- to a Singaporean Company that many middle class Thais became militantly opposed to him. Soon PAD, a coalition between Thai progressive activists, economic political rivals like media mogul Sondhi 
Limthongkul, ${ }^{8}$ and royalists, was formed. Thaksin was attending the United Nations meeting, hundreds of Thais in New York and along the east coast rallied outside the building demanding "Get out Thaksin." At some of the Thai restaurants in the city, the owners put up posters against Thaksin. Outside the UN building the police asked a man and woman who joined the rally with their "We Love Thaksin" signs to leave because they did not have permits to stage a counter-demonstration (Thaksin Greeted 2006). Outside the UN building, Thai Links unwittingly showed solidarity with PAD by wearing yellow shirts, symbolic of their allegiance to the King. ${ }^{9}$ According to David and Susan Morell:

A critical factor in the October 6 (1976) coup was the role of King Bhumiphol Adulyadej, Rama IX. In lending his visible support to the forces of the right, he abandoned a tradition. Always, in the past, he remained officially detached from "politics," thereby making it possible for all citizens to identify with him and, more important, to continue believing that deep in his heart the King was on their side, whatever side that might be. (Morell 1976)

\footnotetext{
${ }^{8}$ In late 2006, Sondhi toured Los Angeles, Seattle, Dallas, San Francisco, and New York to rally support for PAD and for Thais in the US to invest in his satellite television arm of Manager Group, his media conglomerate (Tantipinichwong 2006).

${ }^{9}$ Yellow is the color of the King and in 20062007, royalists and political opportunists alike used the symbolic power of the yellow shirt to express their opposition to Thaksin, who is accused of being anti-monarchical.
}

Both progressives within PAD in Bangkok $^{10}$ and Thai Links have been active in practices of keeping the October memories in circulation, but coalitions formed in a turn of political interests against Thaksin. The PAD from those in the leadership ranks to the everyday restaurant worker in New York donned the yellow shirt, which has become a symbolic social practice of expressing one's allegiance to the crown. The act of wearing the yellow shirt enlisted the monarchy, as an incredible political force imbued with undeniable symbolic power, to various political ends.

For each memory insisted upon, many things are forgotten. The September 2006 military coup against Thaksin was allegedly approved by His Majesty. The high court of Thailand had ruled against Thaksin and his political party Thai Rak Thai from further participation in politics. After his exile to London, Prime Minister Thaksin returned in 2008 with the full support of the government led by Samak Sundaravej, but returned to exile in 2010. Practices of homeland politics abroad, concerning royalist protests against and gatherings for Thaksin at Thai Consulate offices in cities like Los Angeles, Dallas, New York City and Chicago demonstrated that long-distance nationalisms are conflicted. However, these political allegiances to a "virulent nationalism" do not offer liberation, or any subversion against the structure of the state's regulatory power, nor the power of global capitalism. It is in the spaces between

\footnotetext{
${ }^{10}$ Suriyasai Katasila, PAD coordinator in August 2006 had previously organized the October commemorations in Bangkok in 2003 and 2004. In 2003, Suriyasai was a lecturer in the Faculty of Political Science at Thammasat University and an organizer for the Campaign for Popular Media Reform.
} 
Thailand and Washington D.C., Los Angeles, and New York that Thai economic and political transnational subjectivities are forged under conditions of migration and forgetting the 1970s stories of US counterinsurgency in Southeast Asia and its connections to Thai state violence. As such, we must undoubtedly redefine what long-distance nationalist social practices are, not only as actions like voting, demonstrating/ lobbying, sending remittances, creating film/video/art, fighting, killing, and dying for the homeland; but we must interrogate how these social practices remake democracy and belonging, chipping away at the framework of nationalism's exclusionary politics. This is one of the greatest challenges in studying the making of transnational subjects.

\section{References}

Alongkorn Parivudhiphongs. 2004. Short on Film, Long on Content. Bangkok Post, August 5.

Anderson, Benedict. 2001. Western Nationalism and Eastern Nationalism: Is There a Difference That Matters? New Left Review 9: 31-42.

Apinand Bouehapakdee et. al. 1978. Letter from the 'Bangkok 18' to Friends Overseas. Sixth of October Thai United Front for Democracy, May-June.

Appadurai, Arjun. 1996. Modernity at Large: Cultural Dimensions of Globalization, Public Worlds, Volume 1. Minneapolis, Minn.: University of Minnesota Press.
Bandit Rittakol. 2001. Moonhunter. Bangkok: Five Star Productions.

Bao, Jiemen. 2008. From wndering to wat: Creating a Thai temple and inventing new space in the United States. Amerasia Journal 34. 3: 1-18.

Charnvit Kasetsiri and Damrongsak Petchlertanan (ed.). 2001. From 14 to 6 October/ Chak 14 Thueng 6 Tula. Bangkok: Social Sciences and Humanities Textbook Foundation/ Munnithi Khlongkan Tamra Sangkhomsat Lae Manutsat.

Clifford, James. 1994. Diasporas. Cultural Anthropology 9. 3: 302-38.

Desbarats, Jacqueline. 1979. Thai Migration to Los Angeles. Geographical Review 69. 3: 302318.

Hall, Stuart. 1990. Cultural Identity and Diaspora. Identity, Community, Culture, Difference, edited by J. Rutherford. London: Open University.

---. 1996. New Ethnicities. Stuart Hall: Critical Dialogues in Cultural Studies, edited by David Morley and Kuan-Hsing Chen. London: Routledge.

Hu-DeHart, Evelyn. 1999. Introduction: Asian American Formations in the Age of Globalization. Across the Pacific: Asian Americans and Globalization, edited by Evelyn HuDeHart. Philadelphia: Temple University Press.

Kluykiengchon. 2003. Opening of October 14 Festival Progresses: Concert by Gna Chimlang. 
Thai Town USA News, October 2.

Lobe, Thomas. 1977. United States National Security Police and Aid to the Thailand Police. Colorado: University of Denver Graduate School of International Studies.

Morell, David and Susan. 1976. Thailand and the U.S. New York Times, November 22.

Musikawong, Sudarat. 2010. Mourning State Celebrations: Amnesic Iterations of Political Violence in Thailand. Identities: Global Studies in Culture and Power 17. 5: 560-580.

Nidhi Eoseewong. 2002. Considerations about the Politics of History and Memory/ Wa Duai Kanmueang Khong Prawattisat Lae Khwam Song Cham, $1^{\text {st }}$ edition. Bangkok: Matichon.

Ong, Aihwa. 1996. Cultural Citizenship as Subject-Making: Immigrants Negotiate Racial and Cultural Boundaries in the United States. Current Anthropology 37. 5: 73751.

---. 1999. Flexible Citizenship: The Cultural Logics of Transnationality Durham NC: Duke University Press.

---. 2006. Experiments with Freedom: Milieus of the Human. American Literary History 18. 2: 229-44.

Panu Neutini. 2003. Somchai Thaitan Interview. My Thai Newsletter, October.

Randolph, R. Sean, and W. Scott Thompson. 1981. Thai Insurgency: Contemporary Developments.
Washington, D.C; Center for Strategic and International Studies, Georgetown University; Beverly Hills; Sage Publications.

Sassen, Saskia. 2003. The Repositioning of Citizenship: Emergent Subjects and Spaces for Politics. The New Centennial Review 3. 2: 41-66.

Somkiat Wanthana. 1987. The Politics of Modern Thai Historiography. Ph. D Thesis Monash University.

Szanton, William Bradley; David Morell. 1978. Thailand, Domino by Default? The 1976 Coup and Implications for U. S. Policy, with an Epilogue on the October 1977 Coup, Papers in International Studies. Southeast Asia Series; No.46. Athens, Ohio: Ohio Univ. Center for International Studies.

Takaki, Ronald. 1998. Strangers from a Different Shore. Boston: Backbay Books.

Tantipinichwong, Tita. 2006. "Thailand: Anti-Thaksin Leader Rallies Thai Americans" (UCLA based online magazine), April 10. $<w w w . a s i a m e d i a . u c l a . e d u$. asia media>.

Thai Links. 2003. www.Thailinks.Org. October 1, $2006<w w w$.thailinks.org $>$.

"Thaksin Greeted with Protests in New York." 2006. The Nation, September 19.

Thongchai Winichakul. 2002.

Remembering/Silencing the Traumatic Past: The Ambivalent Memories of the October 1976 Massacre in Bangkok. 
MANUSYA: Journal of Humanities, Special Issue No. 18, 2009

Cultural Crisis and Social Memory: Modernity and Identity in Thailand and Laos, edited by Shigeharu Tanabe and Charles Keyes. Honolulu: University of Hawaii Press.

United States Congress. 1977. House of Representatives. Committee on International Relations. Subcommittee on International Organizations. Human Rights in Thailand: Hearings before the Subcommittee on International Organizations of the Committee on International Relations, House of Representatives, Ninety-Fifth Congress, First Session, June 23 and 30. International Human Rights. Washington: U.S. Govt. Print. 